\title{
Günter Altner se jukstaponering van die denksisteme van Schweitzer en Darwin as resiproke korreksies ${ }^{1}$
}

\author{
Johan Buitendag \\ Departement Dogmatiek en Christelike Etiek \\ Universiteit van Pretoria
}

\begin{abstract}
Günter Altner's juxtaposition of the philosophies of Schweitzer and Darwin as reciprocal corrections

The article provides an exposition of the theology of Günter Altner, well-known German scholar in both biology and theology. The article argues that, in Altner's mind, the designs of Schweitzer and Darwin are applied as reciprocal corrections to one another. A juxtaposition is given of the "reverence for life" and "natural selection", which apparently represent the subjective and objective dimensions respectively of Altner's theological design. In order to avoid a naturalistic fallacy, one has to accept that the telos of creation is not an intrinsic value of nature itself, but an eschatological value added to nature. Therefore, appreciation for Altner's handling of the matter is raised, albeit with some reservation with regard to the perhaps overemphasised role ascribed to the human mind.
\end{abstract}

\section{INLEIDING}

Ten spyte daarvan dat lan Barbour (2000) se kategorieë in terme van die spektrum van verhoudings tussen natuurwetenskap en teologie die wydste neerslag in die kontemporêre debat gevind het, kan die driedeling van Günter Altner (2003:89) darem ook nie verbygegaan word nie, te wete 'n verhouding

\footnotetext{
${ }^{1}$ Ek dra hierdie artikel graag op aan die Ou-Testamentikus, Andries Breytenbach, met sy emeritaat as hoogleraar. Hy het menige vermoëns en belangstellings, waarvan skaapboerdery nie die geringste van is nie! Dit is tog opmerklik dat terwyl hierdie artikel basies oor evolusie handel, ons die eerste aanduiding van 'n "oorerflikheidsleer" reeds in die Ou Testament (Gen 30) terugvind - lank voor Mendel se ertjie-eksperimente of Crick en Watson se DNS identifisering! In sy onderhandeling met Laban oor die aantal skape en bokke wat na hom toe sou kom, het Jakob reeds intuïtief aangevoel dat fenotipe deur genotipe bepaal word en het toe gevolglik die resessiewe gene van die diere gemanipuleer (Mitchell 1997:237). Met sy profetiese stem in die NHK, veral die laaste aantal jare, het Andries boonop ook verder aan die bekende Ou-Testamentiese skaapboer van Tekoa herinner!
} 


\section{Günter Altner se jukstaponering van die denksisteme van Schweitzer}

van antitese, sintese of diastase. 'n Klassieke voorbeeld van die antitese tussen teologie en natuurwetenskap is natuurlik daardie welbekende stryd in 1860 (pas na die verskyning van Charles Darwin se On the origin of species) tussen Thomas Huxley en die biskop van Oxford, Samuel Wilberforce met die gevolg dat die Anglikaanse Kerk toe pertinent ook verklaar het dat die beginsel van natuurlike seleksie absoluut teenstrydig met die Bybel is (o a Barrett 2000:99). 'n Voorbeeld van sintese weer is J C Smuts ([1926]1987:9) se siening van holisme in terme van materie, lewe en bewussyn: "We believe in Genesis which by its very nature is epigenesis." As voorbeelde van 'n diastase sou iemand soos Stephen Jay Gould (1999) wees met sy sogenaamde nie-oorvleuelende magisteria tussen teologie en natuurwetenskap. 'n Ander goeie voorbeeld is ook Albert Einstein (1976:22) se sogenaamde twee tale-teorie wat in terme van die verhouding tussen natuurwetenskap en teologie, duidelik onderskei het tussen dit wat is en dit wat behoort te wees. Maar hy gaan ook verder as net dusdanige onderskeid. Dit is twee tale wat mekaar verstaan, wat dus tot'n mate kan konsoneer en wel so dat albei eventueel by 'n soort "kosmiese religieuse gevoel" moet kan uitkom $^{2}$ (Einstein 2000:27-28).

Teologie en natuurwetenskap moet eventueel nie in mekaar oplos nie, maar moet by 'n punt van hipotetiese konsonansie kan uitkom (Peters 2003:19-20). Dit veronderstel uiteraard dat die werklikheid waarmee sowel die natuurwetenskap as die teologie besig is, een en dieselfde werklikheid is en ook aldus verstaan moet word. Selfs die kennende subjek is eners. Geloof en rede is immers altyd vervleg (kyk veral Van Huyssteen 1999:219). En alle uitsprake is ook voorlopig en onderworpe aan gedurige ondersoek, nadenke en revisie. Dit beteken met ander woorde die volgende: enersyds moet die natuurwetenskap dit wat intrinsiek in die natuur is, blootlê en andersyds moet die teologie weer die sin en betekenis van die natuur kan aandui (o a Peters \& Hewlett 2003:22). Die natuurwetenskap sien die skepping dus as natuur en die teologie weer sien die natuur as skepping. Daarom is aposterioriese uitgangspunte in albei gevalle ook baie belangrik (Torrance 1997:102; McGrath 2002:268-272) en word daar dus "from bitter dual to graceful duet" beweeg (Van Huyssteen 1998:131).

Maar dit veronderstel dat die kwessies van die providentia van God en die teodisee altyd weer in die debat onder die loep sal moet kom. As ons Darwin se implisiete materialisme sou probeer oorkom deur natuurlike seleksie aan God se beskikking toe te skryf, dan tref ons die Scylla van 'n God

\footnotetext{
${ }^{2}$ Dit wil dus tog voorkom of Albert Einstein ' $n$ tree verder gegee het as wat Ted Peters (2003:18) dalk toegee (kyk ook Haught 1995:5-6). Alister McGrath (2003:14-16, 271-274) wys in verband met evolusionisme hoe kort die treetjie is van waarneming na geloof toe: empirical observation $\rightarrow$ theory $\rightarrow$ metaphysics (vgl ook voetnota 13 ).
} 
wat wreed voorgestel word en as ons die Charibdis van God se afwesigheid weer sou probeer vermy, gee ons sy almag prys (vgl Van Huyssteen 1998:105). Die uitdaging van die teologie is dus eerder om teïsme so te verstaan dat ons nog in 'n determinisme nog in 'n Goddelike voluntarisme sal verval. Creatio ex nihilo alleen bring altyd 'n deïsme teweeg en creatio continua alleen, weer'n panenteïsme. Wat ons dus in 'n werklikheidsverstaan behoef, is 'n telos waar dit nie kwansuis gaan om die intrinsieke sin van die natuur self nie, maar om die toegevoegde sin wat in Gód setel. Dit beteken dan ook 'n aanvaarding van die concursus van primêre én sekondêre oorsake in die werklikheid. God maak dan nie bloot intervensies nie, maar eerder supervensies. ${ }^{3}$ God se betrokkenheid word dus van binne hierdie een werklikheid uit verstaan. Dit is immanent en ook kontinu; elke oomblik ontvang die totale heelal sy bestaan epigeneties van God af en wel so dat die toekoms oop na vore is. So vorm die toekoms die paradigma vir die geskiedenis (kyk veral Moltmann 1985 en Haught 1995).

Günter Altner - emeritus professor in sowel biologie as in teologie en 'n eminente rolspeler in Duitsland in die geloof en natuurwetenskap debat, die laaste dekade of so eerder ten opsigte van die genetika-etiek - sien self geen eksklusiewe alternatief tussen geloof en rede nie. Deur albei perspektiewe op mekaar te betrek, meen hy, het ons die moontlikheid om veral die tradisionele supranaturalistiese skeppingsbeskouings te korrigeer én om ook die evolusionêre naturalisme aan die kaak te stel. Dit is daarom vir hom van groot belang om die skepping as 'n oop sisteem te verstaan en verklaar hy derhalwe ook herhaaldelik dat die skepping 'n gebeure is. Skeppingsgeloof het vir Altner dan ook nie soseer met die begin van die heelal of die ontstaan van die mens te doen nie, maar eerder met die feit dat dit voortgang en eventueel voltooiing is en 'n nuwe openheid waarborg by die delikate oorgang van 'n gister na 'n môre (Altner 1984:216).

Altner se wyse van teologisering is om eklekties met'n aantal teoloë om te gaan en hulle te laat sê - of selfs te laat násê - wat hy self basies wil oorbring. Vir die skopus van hierdie artikel met sy gemelde twee randstene van voluntarisme en determinisme, word die fokus nou beperk tot Altner se hantering van Albert Schweitzer en Charles Darwin se denksisteme, veral soos uitgedruk in die onderskeie leuses van eerbied vir die lewe en natuurlike seleksie. Wat ek hiermee betoog, is om aan te toon dat wanneer 'n mens Altner se gedagtes in die matrys van 'n subjek-objek paradigma sou laat presipiteer, dit begin duidelik word dat Altner voluntarisme en determinisme

\footnotetext{
${ }^{3}$ Supervensie wil oordra dat "a mental event supervenes on a brain event if and only if that brain event constitutes the mental event, given some specific context" (Murphey \& Ellis 1996:34). Dit is dus ' $n$ tegniese term om die relasie tussen bewussyns- en breineienskappe aan te toon.
} 


\section{Günter Altner se jukstaponering van die denksisteme van Schweitzer}

op hierdie wyse aan die orde stel en wel so dat genoemde twee outeurs korrigerend op mekaar gejukstaponeer word. Self stel hy dit nêrens so eksplisiet nie. ${ }^{4}$

Verwysings en besprekings van genoemde twee outeurs lê ook verspreid in Altner se groot aantal publikasies. Dit kom dus voor of Altner die vrye wil van die subjek kwalifiseer deur erns te maak met die gegewe van die werklikheid waarin dit geworpe is en die meedoënlose voortgang van die natuur te relativeer deur die keuse van die betrokke subjek. ${ }^{5}$ Dit is waarom etiek vir hom so belangrik is. Die speelruimte tussen 'n fiksasie op die vrye wil (mens) en 'n fiksasie op 'n materialistiese predisposisie (natuur) is waar om dit dus vir Altner gaan. Dit is ongeveer ook wat Gilles Deleuze (1987) met sy metafoor van die nomade sou bedoel: nie die berge en die riviere is belangrik nie, maar die grasvelde wat dit alles verbind.

\section{DIE SUBJEKTIEWE POOL}

Volgens Altner (1979:115; 2003:122) het Albert Schweitzer die bewussyn van die mens as die bewussyn van die natuur verstaan. Op hierdie wyse ontstaan 'n soort geestelike eenheid in die heelal. Lewe word dan nie meer as objek gesien nie, maar dit word belewend en voortdurend as subjek eksistensieel ervaar. Sonder die gedurige bewus-wees van hierdie eenheid, bestaan daar ook geen kans op oorlewing nie. Die natuur is daarom geen abstrakte postulaat van optrede nie, maar die bewustelike ervaring van 'n optredesolidariteit. Dit lei uiteraard na 'n etisering van die natuur, maar Altner (1979:116) verstaan dit positief omdat dit'n totaal nuwe horison van kennis en handeling teweegbring. Die radikalisering van die liefdesgebod binne hierdie kader van die skeppingsverantwoordelikheid van die mens, berus ook op die verwagting van 'n nuwe begin waarin die sins- en eksistensiekrisis van die moderne mens van die tegniese beskawing, die nie-menslike natuur as 'n nuwe ervarings horison beleef. En juis dit is die koherensie van die solidariteit en volgens Altner (1980:180), juis ook die bydrae van Schweitzer. Menslikheid beteken solidariteit met álle lewe en daarom prinsipiële gelykwaardigheid van alle organismes. Altner (1975:97) vereenselwig hom daarom ook graag met Schweitzer wat sê dat iemand wat dit besef, "breek geen blaar van 'n boom af nie, pluk geen blom nie, en dra sorg dat hy geen insek dood nie."

\footnotetext{
${ }^{4}$ Uitdrukking hiervan sien mens dalk in Altner (2000:53-72) wanneer hy die objektiwiteit en die subjektiwiteit van natuurondersoek met die betrokkenheid van die wetenskaplike navorser eksplisiet verbind, wat vir hom natuurlik na etiek lei.

${ }^{5}$ Albert Schweitzer $(2000: 125,134-135)$ het uiteraard self kritiek teen Darwin uitgespreek
omdat hy etiek as bloot uitdrukking van kudde-instink gesien het.
} 
Altner (1975:96; 1979:112; 1980:119) fundeer hierdie

eenheidsverstaan in Albert Schweitzer se baie bekende siening van eerbied vir die lewe en meen dat ten spyte van kontemporêre teorieë oor die ekologie, dit as maksime nog steeds ongeëwenaar is. Schweitzer (1949:159) se baie bekende spreuk, ek is lewe wat wil lewe, te midde van lewe wat wil lewe, word dan volgens Altner, die Leitmotiv vir alle etiek. Dit bly egter altyd aangrypend om Schweitzer self te hoor hoe hy tydens sy eerste verblyf in Lambaréné (1913-1917) tot hierdie insig gekom het; hy sinspeel hier selfs op Goddelike openbaring $^{6}$ :

\begin{abstract}
Stadig het ons teen die rivier op beweeg terwyl ons met moeite ons weg tussen die sandbanke deur gesoek het, want dit was toe buite die reëntyd van die jaar (en was die watervlak van die rivier dus baie laag). Eenkant alleen het ek op die dek van die platboomskuit gesit en peins oor die elementêre en algemene verstaan van die etiese wat ek nog in geen enkele filosofie gevind het nie. Ek het bladsy na bladsy vol met onsamehangende sinne geskrywe, net om my te help om op die probleem te bly konsentreer. Teen die aand van die derde dag, toe ons met sonsondergang pas tussen 'n trop seekoeie deurgevaar het, het asof met 'n donderslag, skielik die woorde "eerbied vir die lewe" my voor oë gestaan - sonder dat ek dit vantevore besef het of spesifiek daarna gesoek het. Die ysterdeur (wat my verhinder het om dit te kon sien) het verdwyn en die pad deur die bosse het sigbaar geword. Op hierdie oomblik het ek tot die idee gekom dat wêreld- en lewensaanvaarding altyd saam met etiek te verstaan is! Ek het tot die slotsom gekom dat die wêreldbeskouing van die etiese wêreld- en lewensaanvaarding, saam met sy kultuurideale, in die rede begrond is.
\end{abstract}

(Schweitzer 1949:158; eie vertaling)

Wat is nou egter die basiese veronderstelling van eerbied vir die lewe, vra Altner? Dit impliseer onteenseglike grense vir die menslike praktyk, antwoord hy (Altner 1975:96, 1979:113). Die lewensreg van mense word weliswaar nie ontken of minderwaardig geag nie. Maar die grens van die mens se lewensreg oorskry ook nooit die van die nie-menslike wese nie - ook dáár is immers lewe wat wil lewe. Hiermee vrywaar Schweitzer sy uitgangspunt van enige spanningsvolle fiksasie. Altner (1975:96) meen nou dat die omgekeerde van hierdie beginsel, ewe waar is: die nie-menslike lewende wese vind eweneens ook sy grens in die lewensreg en behoefte van die mens.

Die subjektiewe rol van die mens moet dus altyd binne 'n groter raamwerk gekwalifiseer word (sien hiervoor ook Schweitzer 1949:105).

${ }^{6}$ Schweitzer (2000:128) self sou dit ook later dié geestelike ervaring van mens kon noem. 


\section{Günter Altner se jukstaponering van die denksisteme van Schweitzer}

Ekologies gesproke is dit egter fataal wanneer bepaalde "maksimale groothede" binne 'n stabiele ewewigsisteem na vore sou tree, omdat dit noodwendig ten koste van die balans en dus van die eko-stabiliteit geskied. In hierdie sin was Schweitzer se denke dan ook vir Altner (1980:219; 1979:113) nie bloot misties nie, maar juis ekologies. Hy het immers geen grootheidsbestel daargestel nie (Altner 1980:119). Lewensaanvaarding was vir hom die uitdrukking van die verhouding binne 'n bepaalde lewensgemeenskap wat mens én nie-mens vooronderstel. In hierdie betekenis het Schweitzer sy siening ook teenoor die fundamentele eksklusiwiteit van Descartes se abstrakte dualisme van subjek en objek geponeer (vgl Schweitzer 1949:159). Altner (1975:95; 1979:113) is derhalwe van oortuiging dat die spanning tussen subjek en objek sodoende oorkom kan word.

Altner (1975:97) interpreteer die beginsel van respek vir die lewe ook sodanig dat hy saam met Schweitzer die dood as synde wêreld-immanent, intrinsiek in die natuur wil lees: enersyds is daar geen lewe wat nie ook ten koste van ander lewe geskied nie en andersyds is belangrik dat die prys altyd so klein moontlik moet wees. Die eenheid van die lewe word alleen begryp en gedien as die dood ónontkombaar verstaan en ervaar word. Die grens tussen lewe en dood word ook nie objektief meetbaar aangelê nie, maar subjektief, in die subjek se persoonlike oordeel. Op spoor van Bonhoeffer se Widerstand und Ergebung, gee Altner (1977:70-77) 'n aangrypende beskrywing van die Switserse skilder, Ferdinand Hodler, wat enersyds lydingsvol geprotesteer het teen sy vrou se terminale siekte en andersyds smartvol in haar dood berus het. Aksie en passie deur die dood verenig, staan dus teenoor mekaar soos geskiedenis en natuur.

Alhoewel Schweitzer met sy etiek 'n waardevolle insig verskaf het, oordeel Altner (1979:113), gaan dit nietemin daaraan mank dat die norm sodanig in die individuele bewussyn vasgelê word - waar dit alleen maar op die fyn en sensitiewe gevoel van die spesifieke mens kan appelleer - dat dit ten diepste tog misties vervlugtig. Altner (1975:100) wil daarom eerder'n eerbied vir die lewe sien wat krities met die verobjektiveerde metodiek van moderne navorsing en tegnologie kan omgaan en dood ontologies in die natuur kan vaslê $(1977: 83,1981: 140)$. Daarvoor ag hy juis die insigte van Darwin soos vervat in sy The origin of species, noodsaaklik.

\section{DIE OBJEKTIEWE POOL}

Vir'n meer objektiewe verstaan van die werklikheid sluit Altner hom nou direk by Darwin aan, maar distansieer homself ook eweneens van bepaalde interpretasies daarvan. In soverre daar eerder Grieks-wysgerig as Bybels en 
eerder Haeckeliaans-meganisties as ewolusionêr-Darwinisties gedink word, word tevergeefs aanklank by Altner gesoek. Die evolusieteorie is vir hom slegs die teorie van algemene, historiese afstammingsamehange van organismes. Dit is ook ouer as Darwinisme en dus ook nie Darwin se eie bydrae of prestasie nie (Altner 2003:11-12), maar hoofsaaklik die van sy oupa, Erasmus Darwin, en Jean Baptiste de Lamarck. Dit is ook eerder hierdie teorie volgens Altner (1975:135) wat vanweë sy historiese kategorie, die mens as 'n dier geklassifiseer het. Hier word 'n ontologiese moontlikheid van eenheid tussen dier en mens geponeer. Darwin ([1859]1884:428; sien ook Altner 1975:135) was egter aanvanklik nie direk hierin geïnteresseerd nie en het in die sesde uitgawe van sy The origin of species, maar net heel sydelings opgemerk, "Much light will be thrown on the origin of man and his history." Hy sou eers met 'n volgende publikasie, The descent of man, and selection in relation to sex (1871) hierdie saak aanspreek. (In teenstelling met The origin, figureer hierdie werk van Darwin nie werklik in die publikasies van Altner nie).

Darwin (1979:45) was eerder geïnteresseerd in die oorsake van spesieverandering as in die gemeenskaplike herkoms van alle lewe en het derhalwe gepoog om 'n kousale verklaring van die ewolusie van organismes daar te stel. Sentraal tot Darwin se insig was die waarnemings wat hy gemaak het tydens sy vyf jaar lange vaart (1831-1836) op die HMS Beagle by o a die Galapagos-eilande toe hy bepaalde variasies in spesifieke spesies opgemerk het (Darwin 1979:8). Natuurlike seleksie is dus primêr' $n$ empiriese teorie wat die korrelaat van die vorm, in die funksie van 'n lewende wese gesien het. Die prinsipes wat hierdie korrelaat bepaal, is die van erflikheid en van seleksie (Altner 1971:30, 1974:192, 1975:134,1984:212). Darwin korreleer dus die oorsake vir die mutasies van spesies aan die identifisering van 'n natuurwetlike sameloop van faktore. In terme van die menslike perspektief in hierdie verband, meen Altner (1975:136) nou, was dit veral Ernst Haeckel wat Darwin se natuurlike seleksieteorie geïnterpreteer het as sou dit ewige kousaliteitswette wees wat die geskiedenis bepaal. Dit is die sogenaamde sosiale Darwinisme. ${ }^{7}$

Volgens Altner het Darwin die probleem van oorsprong en voleinding ook nooit probeer beantwoord nie. Waar hy in sy vroeëre uitgawes van die Origin of species dalk nog in 'n mate teleologies gedink het, kon Darwin ([1859] 1884:428) later hoogstens verklaar: "And as natural selection works

\footnotetext{
${ }^{7}$ Dit is interessant dat die nuwe navorsing op hierdie onderwerp toon dat Darwin tóg sosiale pretensies met sy teorie gehad het, veral ten opsigte van die ekonomie; daar word selfs beweer dat hy Adam Smith se The Wealth of Nations as voorveronderstelling gehad het. Kyk hiervoor onder andere McGrath (2003:16).
} 


\section{Günter Altner se jukstaponering van die denksisteme van Schweitzer}

solely by and for the good of each being, all corporeal and mental endowments will tend to progress towards perfection." Die volstrekte geslotenheid van ewolusie soos dan deur Haeckel geïnterpreteer, laat ook nie ruimte vir die Goddelike epifanie nie omdat God met die natuur en substansie monisties geïdentifiseer word (Altner 1971:12). Die Godsbegrip word dan bloot die omskrywing van die absoluutheid van die natuurwet. Die toekoms is daarom vir Altner (1977:78; 1984:210) altyd prinsipieel oop en onvoorspelbaar. Seleksie is ook nooit outark nie. Dit is nie so dat mutasies vanweë oorerwing, die volstrekte materiaal vir die epigeen bied waar seleksie die gepredestineerde rigting van die verandering dikteer nie ${ }^{8}$ (Altner 1984:221). Die variante moontlikhede is egter so legio dat sy toekomstige ontwikkeling net te onvoorspelbaar is. Hiermee wil Altner (1971:147) aantoon dat eerder 'n verskeidenheid van tydsmodi die beslissende gang van ewolusie bepaal. Wetend of onwetend, sê Altner (1984:218), sluit die sosiale Darwiniste hulleself - en daarmee dus die mens - uit van hulle vertolking van Darwin se seleksieteorie. Alhoewel die mens die produk van ewolusie is, is hy dit nie sonder meer nie (Altner 1974:42). Al is sy bewussyn fisiologies in die sentrale senuweestelsel en grootbrein gesetel, gaan dit nie daarin resloos op nie. Altner is hiermee baie na aan Nancey Murphey (1998) se non-reduktiewe fisikalisme. Gevolglik konkludeer Altner nou dat wetmatigheid dus onvoldoende is om die ewolusieproses volledig te beskryf. Die werklikheid is met ander woorde nie net objektief te verstaan nie.

Hoe werk Altner dit nou uit? Naas die noodwendigheid is daar altyd ook die toeval (Jacques Monod). En hierdie ambivalensie konstitueer volgens Altner (1974:138) die seleksieteorie soos dit vandag verstaan behoort te word. Die seleksie druk die toeval uit as doel of plan, of dan objektiewe waarskynlikheid. Dit is belangrik omdat, soos gesien, natuurlike seleksie beïnvloed word deur sowel organiese gemeenskap as die topografiese omgewing (Altner 1974:142). Natuurlike seleksie word met ander woorde gedinamiseer deurdat natuurervaring nou as geskiedenis gekonsipieer word. Wasdom is dan geen suiwer kwantitatiewe grootheid nie, maar juis ook kwalitatief te verstaan (Altner 1974:143). Seleksie en epigenese word dus komplemente van mekaar en so ook fisika en biologie. Kousaliteitswette word met die oop moontlikheid van geskiedenis en ewolusie vervang en word gedokumenteer aan die uniekheid en onvoorspelbaarheid van die resultaat. Die inhomogeniteit van die historiese tyd bring mee dat aanduidings van die

\footnotetext{
${ }^{8}$ Dit was J C Smuts wat hierdie oortuiging met krag ontwikkel het. Kyk byvoorbeeld die volgende stelling van hom (Smuts [1926]1987:89): "Evolution is not merely a process of change, of regrouping of the old into new forms; it is creative, its new forms are not merely fashioned out of the old materials; it creates both new materials and new forms from the synthesis of the new with the old materials."
} 
verlede en voorspellings van die toekoms deur die oomblik altyd agterhaal word. Teoloë en natuurwetenskaplikes besef vandag al hoe meer dat die natuur nie maar net 'n suiwer kenobjek is nie, maar tegelyk ook 'n geïnterpreteerde geheel is (Altner 1974:133).

Aan die een kant is dit vir Altner (1971:16) dus duidelik dat die mens bloot 'n skakel in die ketting van organiese ontwikkeling is, ' $n$ tak in die stamboom van die lewe. Die mens se natuurlike eienskappe straal bepaalde etappes af wat die ontwikkeling van die lewe op die weg na sy menswording aandui. Met die Primate deel die mens die spesie homo (Altner 1974:36). En hierdie spesie dateer soveel as 160 miljoen jaar terug (Altner 1971:17). Gesien vanuit die perspektief van die ekologie, konstateer Altner (1971:84) dan onomwonde, beskik die mens ook oor geen besondere prioriteitsposisie in die natuur nie. Trouens, geen spesie kan hierop aanspraak maak nie. Die begrip ekosisteem transendeer die fenomeen spesie immers duidelik. Vanweë hierdie biologiese solidariteit, distansieer Altner (1974:38) hom ook eksplisiet van Hegel se begrip van die idealistiese mens wat in hoogmoed van 'n gedegradeerde natuurbegrip verabsoluteer is. Dit wil egter nou ook nie aan die ander kant sê dat die mens ook nié oor 'n bepaalde "eksnaturaliteit" beskik nie (Altner 1974:86). Ons sou dit in positiewe sowel as in negatiewe sin kon sistematiseer. Die beslissende skrede hiervan, meen Altner (1971:17) is die oorgang van die seediere na die landdiere. Altner $(1971: 23,146)$ sien saam met Gerhard Heberer die DMO (dier-mens-oorgangsveld) as die konstituerende fase van die mens se ewolusie. Daar is dus 'n subhumane fase, die DMO en die humane fase. Die paleontologiese ontwikkeling word hierin ook deeglik in berekening gebring wat enersyds op die werktuie en andersyds op die selfgeponeerde uitdagings van hierdie spesie slaan. Tog is die betekenis van die DMO nie daarin geleë dat dit enige antwoorde bied nie, maar eerder dat dit die probleem uiteensit. Die natuur bied eenvoudig nie enkelvoudige kriteria vir die begin van die menswording nie - die Offenheit bleibt (Altner 1971:63). Die toenemende komplisering van die subjek-objek verhouding binne die terreine van die fisika, die biologie en die antropologie, weerspieël dan ook juis die geheimenis wat in die hoëre ontwikkeling van die lewe gerealiseer het (Altner 1971:46).

Die mens is dus nie net 'n natuurwese nie, maar juis ook 'n menslike natuurwese (Altner 1971:67). Hy staan in 'n verhouding tot sowel die voorhande objektewêreld van die natuur, as tot die subjektewêreld van die geskiedenis. Daarom is hy ook die ensemble van sosiale verhoudinge. Enersyds is hy binne 'n natuurlike determinasie, andersyds binne 'n sinsoekende selfbestemming (Altner 1971:56). Die mens beskik ook altyd oor 'n veto-vermoë - om te konformeer of nie - wat hom van die algemene 


\section{Günter Altner se jukstaponering van die denksisteme van Schweitzer}

natuurwesens onderskei en dit maak dit vir hom moontlik om volgens die beginsels van sy kenvermoë en die norme van sosiale verantwoording, sy gestalte te profileer (Altner 1984:222). As 'n enkele subjek, is hy burger van twee ryke, elk met sy eie wette. Steeds is hy egter onderweg tussen sy natuurlike gister en sy sosiale môre - en juis dit is sy andersheid. Ten spyte van bepaalde egoïstiese elemente in die mens se verhouding, word hy nietemin geken aan 'n bewustelike altruïsme (Altner 1984:222). Die feit dat hy ook ander ' $n$ kans bied, is 'n morele postulaat ${ }^{9}$ wat nie in die nie-menslike wêreld bestaan nie (Altner 1971:61). Die mens is dus op weg, in proses, en het lank nog nie sy finale gestalte ontvang nie (Altner 1984:223). In die pendulebeweging tussen sy verlede en sy toekoms, ook wat is en wat behoort te wees, lê die mens se hoop in 'n oop toekoms (Altner 1971:55, 2003:121). Hier lê dan ook sy godsdienssin en is hy op weg binne 'n kosmiese wêreldproses as skepping van God (Altner 1984:223).

Daar moet nou darem ook op die mens se negatiewe "eksnaturaliteit" gewys word. Dit is daarin geleë dat die mens die natuur nog altyd verdinglik het, sê Altner (1974:49). Of dit nou deur die primitiewe mens se knuppel of spies was en of dit deur die moderne mens se geweer of spuitnaald geskied, feit bly dat die mens niemand of niks buiten homself subjektiwiteit gun nie; ja, sy eie biologiese geskiedenis annihileer hy (Altner 1974:54). Die gevolge hiervan is duidelik. Die homo sapiens is dus in die sin ekologies ook uit te sonder dat hy 'n besondere steurnis in die stabiliteit van die biosfeer teweeggebring het (Altner 1971:85).

Altner (1977:78) sien die dood altyd as 'n soort van diskrete begeleier van die lewende organisme. Lewe veronderstel per definisie die dood, omdat dit' $n$ wedloop van konkurrerende variante immanent het (Altner 1979:114). Dit gee aan die dood ontologiese status. Altner (1981:140) betreur dit dat die dood dikwels beskou word as dit wat aan die einde van die lewe eers kom. Dit pas ook nie by sy tydsverstaan nie. Die korrekte verstaan van die dood, meen Altner (1977:77), oorbrug juis die dualisme tussen die ervaring van die lewe en die deelname daaraan, tussen geskiedenis en natuur. Die subjek-objek skeiding word oorkom deur'n koherente ontwerp van ervaring, omdat daar sodoende 'n innerlike verhouding tussen subjekte tot stand kom. Die ewolusieproses is sodoende die substraat van hierdie samehang, omdat dit 'n

\footnotetext{
${ }^{9}$ Altner $(1971: 61,63)$ illustreer dit met die voorbeeld van die ingewikkelde debat oor aborsie. Om suiwer biologies te redeneer en te vra van watter oomblik af die embrio ' $n$ mens is, is futiel. Watter kriteria moet aangewend word? Is die fetus eers mens wanneer sekere organe soos byvoorbeeld die brein onderskei kan word? Wat beteken onderskeiding in die verband? Of begin menswording eers wanneer die fetus selfstandig kan beweeg? Of moet ons teruggaan na die sigoot? Nee, die natuur alleen kan hier nie antwoorde bied nie, sê Altner. Hier benodig ons ' $n$ omvattende gesigspunt wat die natuurlike met die morele verbind.
} 
oop en dinamiese toekoms waarborg. Trouens, natuur is geskiedenis (Altner (2003:11).

\section{DIE VOLHEID VAN DIE TYD}

Die natuur gaan nooit resloos in die menslike werklikheidservaring op nie. Alhoewel kosmogenese, biogenese en noögenese (Teilhard de Chardin) 'n akkurate beskrywing van ewolusie is, wat hetsy deur ' $n$ immanente transendensie, hetsy deur 'n bepaalde kwaliteit gerig word, moet steeds gehandhaaf word dat dit nie die volledige prentjie skilder nie. Nie die geskiedenis nie, maar die eskatologie vorm vir Altner (1980:153) daarom die keersy van die natuur. Hieruit is dit duidelik dat Altner (1974:21) dus nóg 'n utilistiese beskikking oor die transendensie van menslike geskiedenis (Nietzsche) wil nahou, nóg 'n ontkenning van die transendensie omdat die geskiedenis en toekoms kwansuis gedetermineer is (Amery 1972). Eerder wil hy (Altner 1980:153) vir Karl Rahner nasê, wat tussen die ewolutiewe en die nie-ewolutiewe, die ekstrapolerende en die antisipatoriese, die progressus terrenus en die eskatologiese gawe, onderskei. Rahner het immers al gewaarsku dat hierdie tegnies-meetbare en ewolutiewe-sigbare nooit met die eintlike toekoms verwar moet word nie; Gees en materie is immers nie sinonieme nie (Rahner 1968:190). Dit is ook Altner (1980:153) se kritiek teen baie ekologies-bewuste bewegings soos 'n "anti-atoomkrag-aksie" of 'n "reddie-voëllewe-aksie" wat meen dat hulle die toekoms sélf moet bewerk omdat ' $n$ bepaalde daad $A$ van die hede tot ' $n$ noodwendige resultaat $B$ van die toekoms moet voer. Wat weet ons in elk geval van die toekoms af?, vra hy. Tussen dit wat reeds gerealiseer het en dit wat nog uitstaande is, is daar altyd 'n felle spanning (Altner 1971:159). Die Godsvraag is hiermee nog lank nie opgelos nie, sê Altner, maar ten minste het valse godsbeelde in die slag gebly. Die natuur is immers altyd Schöpfung im Werden. Die teoretiese bemoeienis met Darwinisme roep dus ook teleologiese dimensies op.

Die werklikheid is daarom die vraag na die volheid en die ewigheid is wat die Godsvraag veronderstel (Altner 1981:115). Die vraag na die ewigheid word geponeer as synde 'n vraag na regverdiging - die teodiseevraagstuk omdat natuur en geskiedenis in hierdie wêreld as 'n dodelike skermutseling met kosmiese afmetings ervaar word. Dit is dan die koördinaatasse van die werklikheid van die leweskeppende God (Altner 1977:69). Omdat dit 'n oorlewingsvraag is, is dit net logies dat, soos Heidegger gesê het, die mensheid, in sy dreigende ondergang, hom op die komende God moet oriënteer (Altner 1980:128). Die kennis wat die mens oor sy sterflikheid het, roep die bestaan van God op. Geloof in die almag van die Skepper is tegelyk ook erkenning van die swakheid van die mens (Altner 1980:124). 


\section{DIE KORREKTIEF}

Altner (1975:98) wil sy probleem met Schweitzer se eerbied vir die lewe, beantwoord met' $n$ objektief-verifieerbare grens waarbinne opgetree moet word: "Weiß Schweitzer nicht, daß die Erforschung des Lebens nun einmal notwendigerweise messend und objektivierend sein muß?" Hierdeur verbind hy spesifiek die dinamiek van menslike geskiedenis en maatskaplike ontwikkeling met die kringloop van die natuur (Altner 1974:187). 'n Dialektiek tussen ervaring en kennis ontstaan dan omdat 'n komplementariteit speelruimte tussen kwaliteit en kwantiteit, tussen die ossillasie van geskiedenisbelewing en wêreldordeninge, realiseer (Altner 1974:165). Lewenskwaliteit word nou so wyd moontlik opgevat deurdat dit'n verskeidenheid van dimensies daarstel wat tyd-ruimtelike netwerke konsipieer waarbinne die interafhanklikheid van die onderskeie enkelkwaliteite herkenbaar word. Ten opsigte van die kwaliteit van lewe, word die ekologiese dimensie net so noodsaaklik geag as die sosio-kulturele voorwaardes (Altner 1975:162). Dit behels dat die waardesisteem van 'n gemeenskap op 'n gelyke vlak as ekonomiese en politieke ordeninge is; so ook die materiële as die immateriële; die regte en pligte van die enkeling as die bevoegdheid van gemeenskapsinstitusies; die posisie van die hede as die moontlike toekomstige veranderings. En dit bring 'n planetariese solidariteit teweeg (Altner 1974:164). En hier lê die belang van die eerbied vir die lewe.

Skeppingsgeloof gaan vir Altner ook om aanvang én voortsetting. God is die Een wat dit wat nie bestaan nie, in aansyn roep, volgens Romeine 4:17

“... God wat dooies lewend maak en dinge wat nie bestaan nie, tot stand bring deur sy woord" (Altner 1977:69; 1980:157; 1984:199). Dit verwys analogies na die regverdiging van die sondaar wat uit sy nietigheid weer gebore word (Altner 1974:135). Daarom is skeppingsgeloof vir Altner (1971:73) ook die ontwikkeling van lewe. Altner (1971:76) sien 'n klassieke bewys vir'n teologie van creatio continua in 1 Joh 3:2 - "Dit is nog nie geopenbaar wat ons sal wees nie, maar ons weet dat, wanneer Jesus kom, ons soos Hy sal wees" omdat dit hierin om 'n kontinue en voortstuwende geskiedenis gaan. Die skeppingsgeskiedenis, sê Altner (1971:73), is dus geensins met die eerste hoofstukke van die Bybel klaar vertel nie. Dit is die voorgeskiedenis, die prelude van wat volg en met die apokaliptiese visioene eindig. Hierdie skeppingsberigte benut die wêreldbeelde van hulle tyd om die creatio ex nihilo te kommunikeer, maar skilder ewe-eens die skeppingsvoortgang in en met die tyd, wat deur die skeppingsweek onderstreep word (Altner 1984:216; 1980:158). Omdat die tyd met alles geskape is, het dit ook'n aanloop, ' $n$ verloop en ' $n$ afloop - verlede, hede en toekoms. God se heilshandeling met sy kosmiese tendens en uitstaande einde, vind sy kontinuïteit in sy trou 
(Altner 1974:60). Met die ganse skepping wag die Christendom op die komende Here (Altner 1971:73). Die diskontinuïteit van God se heilshandeling lê daarin dat God tyd aanneem en geskiedenis en natuur rig (Altner 1974:135). So is die inkarnasie ' $n$ beslissende skrede in hierdie dinamies agerend-reagerende werking van God in die geskiedenis (Altner 1971:73). Die geskiedenis behou sy eenheid met die natuur en dus sy sin, by wyse van die Goddelike werklikheid. Solidariteit met die nie-menslike kreatuur is vir die mens daarom ' $n$ basiese gegewe (Altner 1984:184). Mens en nie-mens het sowel 'n gemeenskaplike herkoms as toekoms (Altner 1974:137, 1975:90). Hierdeur erken Altner God dus as die betrokke Skepper wat alles in die toekoms tot volvoering bring.

\section{SAMEVATTING}

Gesien in die lig van die feit dat Altner die groot uitdaging van die teologie daarin sien dat natuur en kultuur bevredigend moet kan verbind, is dit vir hom belangrik dat die objektiwiteit van die seleksieteorie met die subjektiwiteit van die eerbied vir die lewe moet korrespondeer. Hiermee word' $\mathrm{n}$ determinisme oorkom. Ruimte word ook aan die subjek gebied deurdat die objektiewe waarskynlikheidsgestalte van 'n toekomende organisme deur minstens sowel die organiese gemeenskap as die topografiese omgewing van die huidige subjek bepaal word, met die gevolg dat die oop toekoms 'n legio moontlikhede waarborg. Op hierdie wyse verbind Altner subjek en objek dialekties en word geskiedenis as natuurervaring verstaan. Soos wat fotone golwend of korpuskulêr voortgeplant word afhangende van die keuse van die subjek, kompleteer seleksie en epigenese mekaar ewe-eens. Kousaliteit en kontingensie word derhalwe komplemente en word die moontlikheid van 'n transendente immanensie blootgelê. Sonder 'n eskatologie is die geheel van die werklikheid nog nie klaar gedefinieer nie (Altner 1975:149; 2003:117-123).

Die eerbied vir die lewe vind sy korrelaat in die grense wat daar vir die wasdom voorsien word. Die eerbied vir die lewe postuleer 'n geestelike verhouding tot die universum binne die bewussyn van die etiese agent. Die radikalisering van die liefdesgebod laat die nie-menslike natuur as 'n nuwe ervaringshorison beleef. Die prinsipiële gelykheid van alle lewe verander medemenslikheid na medekreatuurlikheid en Christus word nie net in die medemens in nood ontmoet nie, maar ook in die sugtende natuur. Hieruit word 'n mistieke subjektivisme gebore wat die grense van die lewe self bepaal. Die innerlike bekering van die individu, gestu deur die verdoemende feite van objektiewe studies, voer nou vir Altner tot ' $n$ modus vivendi waar die slagspreuk nie meer is om gedien te word nie, maar om self te dien. ' $n$ Askese 


\section{Günter Altner se jukstaponering van die denksisteme van Schweitzer}

hipostaseer sodanige oortuiging wat dan nie net bloot onthouding beteken nie, maar weerstand teen alle outonomie, antroposentrisme en absolutisme.

Altner lees dus uit die kontoere van die lewensbedreiging juis die aanbod van die lewe, ja van die ewige lewe (Altner 1980:157). Die mens se besondere posisie binne hierdie geskape werklikheid grond dan daarop dat hy van hierdie situasie bewus is en dienooreenkomstig in die geskiedenis handel - of dit nou deur aanvaarding en of dit nou deur verwerping van die sterflikheid is (Altner 1984:217). Solidariteit tussen mens en nie-mens is vir Altner dus altyd sowel organies-onties as lydend-eties. 'n Simbiose word gevolglik veronderstel (Altner 1977:271). Die lewe kan net nagevors en gerespekteer word as koöperatief daarin gedeel word. En deelname beteken natuurlik medelye en uiteindelik ook oorgawe.

\section{WAARDERING}

Die antwoord tussen die gemelde Scylla van 'n determinisme en Charibdis van 'n voluntarisme moet nie daarin gesoek word dat 'n intrinsieke eenheid in die natuur blootgelê word asof die natuurwetenskap eventueel 'n selfstandige teleologie kan aanbied nie, maar wel so dat die betekenis van 'n skeppingsgeloof daarby gevoeg word. Hierdie proses is 'n eskatologiese onderneming en alleen die teologie kan by hierdie veronderstelde geheel uitkom (Altner 1975:149). Epigenese kan dan so verstaan word dat naas die skepping, hérskepping geantisipeer word. Die sin en doel van die skepping setel dus nie in die natuur nie, maar in Gód. Altner is dus inderdaad op die regte spoor met sy resiproke korreksies en sy eskatologiese perspektief.

Altner se hantering van die teodisee-vraagstuk is daarom ook op die regte koers. Lyding kan nie regtig afdoende deur natuurlike seleksie gehanteer word nie. Om lyding bloot as die gevolg van die stryd om oorlewing te sien en derhalwe suiwer natuurlik, is eenvoudig 'n te hoë prys vir die teologie om te betaal. Die kosbaarste insigte om in hierdie verband perspektief te kry, kom van Martin Luther (1989) se teologie van die kruis waardeur hy die kruisgebeure paradoksaal uitlê en dit sub contrario specie verstaan. ${ }^{10}$ God openbaar Homself juis in sy verborgenheid. Goddelike opname van lyding is nie aanvaarding daarvan nie, maar juis die omgekeerde en spel daarom nie dood uit nie, maar lewe. Ons verwys immers na Goeie Vrydag en nie na Swart Vrydag nie! Dit is ook wat byvoorbeeld George Murphy (1986:xi) bedoel met sy "giasmiese Christologie" deurdat Christus se teenwoordigheid in die skepping "cross-shaped" is. Op spoor van Pannenberg

\footnotetext{
${ }^{10}$ Dit is opmerklik dat ons mense vandag hierdie wyse van verstaan laat verbygaan. In geen van die baie reaksies op Mel Gibson se beroemde rolprent, The Passion of the Christ (2004), het ek hierdie perspektief teengekom nie.
} 
kan Peters \& Hewlett (2003:173) daarom ook verklaar dat die teodiseevraagstuk 'n teologiese kwessie is, nie 'n logiese nie. Nie die "survival of the fittest"11 met sy gepaardgaande uitskotte van gebreke, geweld en dood beantwoord dit nie, maar wel God se belofte van opstanding en herstel van die skepping. Dit is waarom 'n theologia naturalis deur'n theologia naturae gekwalifiseer moet word.

Dit is ten slotte tog 'n ope vraag of Altner nie eventueel óórkompenseer en die subjektiewe pool oorspan nie. Sit hy nie steeds maar met die gedagte dat die impuls van sowel die diastase as die koherensie tussen natuur- en mensgeskiedenis, in die menslike bewussyn geleë is nie? Beteken dit nie maar steeds dat die mens eers innerlik van die wêreld bevry moet wees waarna hy hom dan uiterlik na die wêreld kan wend nie? Lê die eenheid tussen gees en stof nie maar steeds in 'n innerlike oortuiging met sy gepaardgaande sigbare handeling nie? Is dit nie maar steeds ék wat God en wêreld by mekaar uitbring nie? Altner se dilemma is dus dat hy met 'n konkrete individualiteit werk wat magteloos is vanweë sy viktimologiese eksistensie en tegelyk met 'n abstrakte kollektiwiteit wat ewe magteloos is vanweë sy doketiese gestalte. Die oplossing van Hefner (1993:128-142) om die mense as 'n geskape medeskepper te sien, oorkom sodanige fiksasie dalk beter. Ten diepste is Altner se teologie nie die van die natuur nie, maar die van die mens self; dit is geen theologia naturae nie, maar' $n$ theologia hominis. Verraai Altner (1979:114) dalk nie homself wanneer hy laat uitglip, "Es geht letzlich um das Überleben des Menschengeschlechts"? 'n Mens wonder of hy regtig 'n subjektivisme kan oorkom, in elk geval nie 'n antroposentrisme nie.

Geloof en rede kan nie los van mekaar verstaan word nie. Die jongere Darwin het in die eerste uitgawes van sy (toe nog "On") The origin of species, geloof en rede komplementêr gesien, en het die betoog begin met 'n aanhaling van Francis Bacon se Advancement of learning (1605) waardeur Darwin ons oproep om sowel die boek met God se woorde as die boek met God se werke te lees. ${ }^{12}$ Alhoewel Darwin as kind van sy tyd, die induktiewe metode vir sy wetenskaplike arbeid nagevolg het, het hy dit nietemin kreatief gedoen en sou mens sy metodiek dalk eerder die van hipoteties-deduktief kon

\footnotetext{
${ }^{11}$ Hierdie uitdrukking het Darwin eers in die vyfde uitgawe van sy The origin of species die eerste keer gebruik. Vir 'n goeie vergelykende studie van die redaksionele wysigings wat Darwin oor sy ses uitgawes aangebring het, sien die uitgawe van Morse Peckham (Darwin 1959).

${ }^{12}$ Die invloed wat William Paley se Natural theology (1802) op Darwin gehad het word netjies deur Ayala (2003:9-21) aangedui. Ayala lees The origin so dat Darwin, netsoos Paley, op kwessie van ontwerp in die natuur ingegaan het. Die verskil was net dat Darwin hom nie op metafisiese hipoteses vir finale sin wou verlaat nie. Sien ook Altner (2003:16-36) in hierdie verband en veral ook die invloed wat Darwin se skoonfamilie, die Wedgwood-familie (bekende miljoenêrs in die porseleinbedryf) op hom gehad het.
} 
noem (o a Altner 2003:23; Barrett 2000:97), 'n vervlegting van waarneming en intuïsie ${ }^{13}$ dus. Dit is dieselfde werkwyse wat ook Altner met sy eerbied vir die lewe en natuurlike seleksie volg. Mens kan Altner se ontwerp in terme van Peters (2003:21) se kategorieë, daarom primêr plaas by die van etiek.

Maar ons moet altyd ook by 'n konsonansie uitkom, al is dit voorlopig. Raakvlakke tussen teologie en natuurwetenskap moet nie alleen in optrede bestaan nie, maar vra 'n teïstiese verstaan van evolusie wat God prinsipieel as die "ultimate basis" (Ward 1998:122) aanvaar. En hierdie God - wil ons saam met Thomas Torrance (2001:148) graag byvoeg - is geen ander God as die Drie-enige God nie.

\section{Literatuurverwysings}

Ayala, F J 2003. Intelligent design: The original version. Theology and Science I, 932.

Altner, G 1971. Grammatik der Schöpfung: Theologische Inhalte der Biologie. Stuttgart: Kreuz.

Altner, G 1974. Schöpfung am Abgrund. Die Theologie vor der Umweltfrage. Neukirchen-Vluyn: Neukirchener Verlag.

Altner, G 1975. Zwischen Natur und Menschengeschichte. Anthropologie, biologische, ethische Perspektiven für eine neue Schöpfungstheologie. München: Chr. Kaiser.

Altner, G 1977. Die Trennung der Liebenden: Variationen über den Ursprung des Lebens. Evangelische Theologie 37, 69-83.

Altner, G 1979. Wahrnehmung der Interessen der Natur, in Meyer-Abich, K M (Hrsg), Frieden mit der Natur, 112-131. Freiburg: Herder.

Altner, G 1980. Leidenschaft für die Ganze. Zwischen Weltflucht und Machtbarkeitswahn. Stuttgart: Kreuz.

Altner, G 1981. Tod, Ewigkeit und Überleben. Heidelberg: Quelle \& Meyer.

Altner, G 1984. Fortschritt Wohin? Neukirchen-Vluyn: Neukirchener Verlag.

Altner, G 2000. Natur im Spiegel biologischer Außenseiter im 20. Jahrhundert, in Altner G, Böhme, G \& Ott, H (Hrsg), Natur erkennen und anerkennen, 53-72. Zug/Schweiz: Die Graue Edition.

Altner, G 2003. Charles Darwin - und die Dynamik der Schöpfung. Gütersloh: Gütersloher Verlaghaus.

Amery, C 1972. Das Ende der Vorsehung. Die gnadenlosen Folgen des Christentums. Hamburg: Rohwolt.

Barret, P 2000. Science \& Theology since Copernicus: The search for understanding. Pretoria: University of South Africa.

Barbour, I 2000. When science meets religion. New York: HarperCollins.

Darwin, C [1859] 1884. The origin of species by means of natural selection. 6th ed. London: John Murray.

\footnotetext{
${ }^{13}$ Kyk McGrath (2003:271-274) vir die invloed wat byvoorbeeld ook William Whewell se nosie van consilience Darwin beïnvloed het. Dit is hierdie ideologiese vervlegting wat nog altyd die grootste probleem vir die kreasioniste is.
} 
Darwin, C 1959. The origin of species by Charles Darwin: A variorum text, ed by M Peckham. Philadelphia, PA: University of Pennsylvania.

Darwin, C 1979. The illustrated origin of species by Charles Darwin, abridged \& introduced by Richard E Leaky. London: Faber \& Faber.

Deleuze, G \& Parnet, C 1987. Dialogues. New York: Columbia University.

Einstein, A 1976. Out of my later years. New York: Citadel.

Einstein, A 2000. The world as I see it. New York, NY: Kensington Publishing Corp.

Gould, S J 1999. Rock of ages: Science and religion in the fullness of Life. New York: Ballantine.

Haught, J F 1995. Science \& Religion. New York: Paulist Press.

Hefner, P 1993. The human factor: Evolution, culture and religion. Minneapolis, MN: Fortress.

Luther, M 1989. Martin Luther's basic theological writings, ed by T F Lull. Minneapolis, MN: Fortress.

McGrath, A E 2002. A scientific theology: Reality, Vol 2. London: T \& T Clark.

McGrath, A E 2003. A scientific theology: Theory, Vol 3. London: $T$ \& T Clark.

Mitchell, C B 1997. The church and the new genetics, in Kilner, J F, Pentz, R D \& Young, F E (eds), Genetic Ethics: Do the ends justify the genes? 230-245. Grand Rapids, MI: Eerdmans.

Moltmann, J 1985. Gott in der Schöpfung. Ökologische Schöpfungslehre. München: Chr. Kaiser Verlag.

Murphey, N 1998. Nonreductive physicalism: Philosophical issues, in Brown, W, Murphey, N \& Malony, H N (eds), Whatever happened to the soul? 127-148. Minneapolis, MN: Fortress.

Murphey, N \& Ellis, G F R 1996. On the moral nature of the universe. Minneapolis, MN: Augsburg Fortress.

Murphy, G L. 1986. The trademark of God. Connecticut, CT: Morehouse-Barlow.

Peters, T 2003. Science, theology and ethics. Burlington: Ashgate.

Peters, T \& Hewlett, M 2003. Evolution from creation to new creation. Nashville, TN: Abingdon.

Rahner, K 1968. Schriften zur Theologie, Band V. Zürich: Benziger Verlag.

Schweitzer, A 1949. Uit mijn leven en denken. Geautoriseerde vertaling van H M Eigenhuis-van Gent. Haarlem: H D Tjeenk Willink \& Zoon N V.

Schweitzer, A 2000. Reverence for life, ed by M Meyer \& K Bergel. New York: Syracuse University Press.

Smuts, J C [1926] 1987. Holism and evolution. Cape Town: N \& S Press.

Torrance, T F 1997. God and rationality. Edinburgh: T \& T Clark.

Torrance, T F 2001. The ground and grammar of theology. Edinburgh: T \& T Clark.

Van Huyssteen, J W 1998. Duet or dual? Theology and science in a postmodern world. Harrisburg, PA: Trinity Press International.

Van Huyssteen, J W 1999. The shaping of rationality: Toward interdisciplinarity in theology and science. Grand Rapids, Ml: Eerdmans.

Ward, K 1998. God, faith \& the new millennium: Christian belief in an Age of Science. Oxford: Oneworld. 